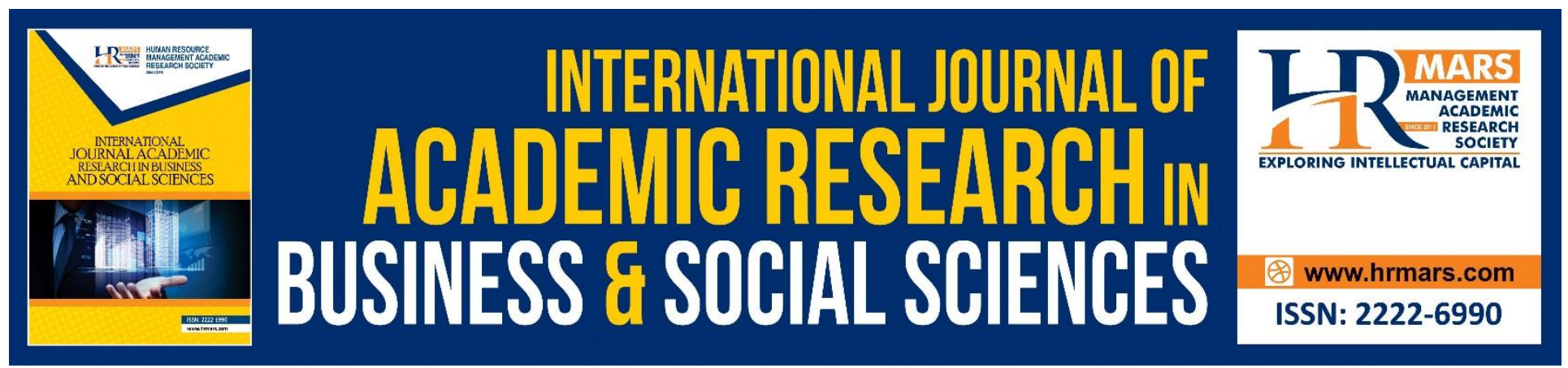

\title{
The National Model of Philanthropy towards the Global Philanthropic Practices
}

\author{
Mohd Farhan Ahmad, Mohd Ali Muhamad Don, Mahfuzah Mohamed Zabidi, \\ Rohaya Sulaiman, Azizah Md Kasah
}

To Link this Article: http://dx.doi.org/10.6007/IJARBSS/v8-i11/4955

DOI: $10.6007 /$ IJARBSS/v8-i11/4955

Received: 13 Oct 2018, Revised: 27 Oct 2018, Accepted: 17 Nov 2018

Published Online: 23 Nov 2018

In-Text Citation: (Ahmad, Don, Zabidi, Sulaiman, \& Kasah, 2018)

To Cite this Article: Ahmad, M. F., Don, M. A. M., Zabidi, M. M., Sulaiman, R., \& Kasah, A. M. (2018). The National Model of Philanthropy towards the Global Philanthropic Practices. International Journal of Academic Research in Business and Social Sciences, 8(11), 791-799.

Copyright: (C) 2018 The Author(s)

Published by Human Resource Management Academic Research Society (www.hrmars.com)

This article is published under the Creative Commons Attribution (CC BY 4.0) license. Anyone may reproduce, distribute, translate and create derivative works of this article (for both commercial and non-commercial purposes), subject to full attribution to the original publication and authors. The full terms of this license may be seen

at: http://creativecommons.org/licences/by/4.0/legalcode

Vol. 8, No. 11, 2018, Pg. 791 - 799

http://hrmars.com/index.php/pages/detail/IJARBSS

JOURNAL HOMEPAGE

Full Terms \& Conditions of access and use can be found at http://hrmars.com/index.php/pages/detail/publication-ethics 


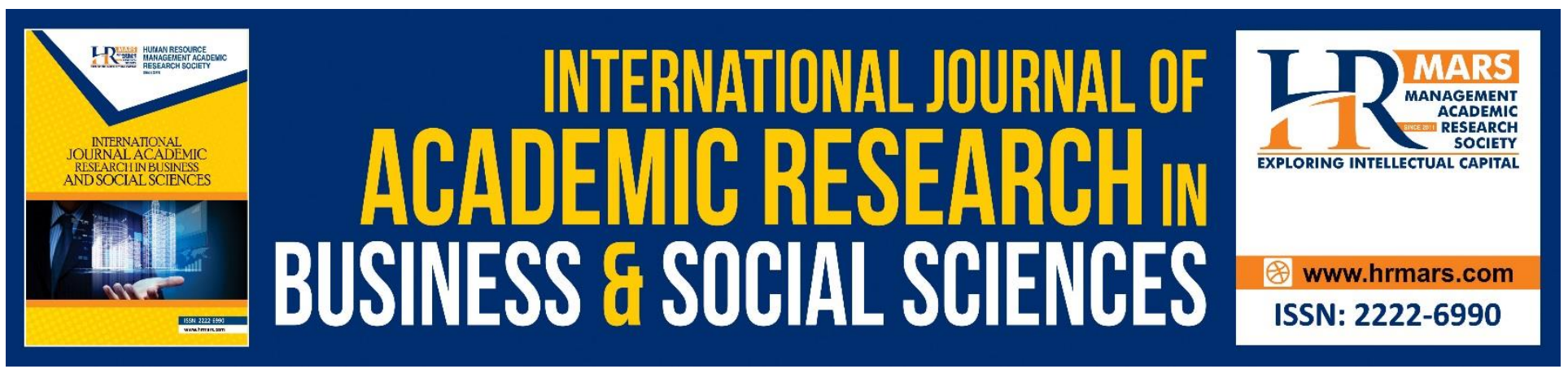

\title{
The National Model of Philanthropy towards the Global Philanthropic Practices
}

\author{
Mohd Farhan Ahmad, Mohd Ali Muhamad Don (PhD), \\ Mahfuzah Mohamed Zabidi (PhD), Rohaya Sulaiman, \\ Azizah Md Kasah \\ Johor, Malaysia.
}

\begin{abstract}
Our world is facing the 4th wave of industrial revolution whereby machines and technology are taking over humans' role. There has been concerns that humanistic values like an act of generosity within the society is dwindling due to this advancement. Philanthropic contribution is seen as a method to adverse the said impact. Still, this is dependent to the willingness of an individual to contribute as well as the knowledge of effective philanthropic mechanism. The practice of philanthropy is yet to become a nationally accepted culture as the number of the poor is increasing day by day. Besides, there has been a few cases of documented embezzlement of philanthropic funds that causes the public to be skeptical of the credibility of these philanthropic organizations; hence stopping them from contributing. Therefore, the aim of this study is to suggest a manual or guidelines to implement philanthropic practice nationwide. The data and information field regarding philanthropic practice amongst philanthropists are collected through semi-structured interviews from selective participants by purposive sampling method. Interview data is analyzed by using Atlas.ti and presented in the form of a final report. With this guidelines, any organization can adopt it for enculturing the philanthropic practices in their workplace and lives.
\end{abstract}

Keywords: Islamic Philanthropy, Philanthropic Practices, National Model of Philanthropy

\section{Introduction}

Philanthropy is an important tenet of Islam because the concern for the needy and almsgiving is one of five pillars that forms the foundations of Islam. The term Islamic philanthropy refers to private goods given in accordance with Islamic ordinance of charitable giving for public purposes. Philanthropy is based on the principle that everything on earth belongs to Allah and human being are only a trustee for all that wealth. Allah bestowed some property on some so that they can be grateful and help others in charity. 
In our society, Islamic philanthropy plays an important role in strengthening the ummah. Towards become a developing and prosperous country, in Malaysia there are still a handful of citizen who undergo low standards of living on pressures and problems such as economics, health and the environment. It can be seen through various evidence of Islamic philanthropy excellences throughout the century worldwide. It can be track back to the time of Prophet Muhammad and Khulafa' AlRasyidin followed by the reign of Islamic empires.

However, the culture of philanthropy has not yet been practiced widely among Malaysian citizen, as compared to other country such as Indonesia. In the other hand, the current philanthropic practices are still not adequate to meet the needs of the community. Therefore, this paper attempts to suggest a guideline on how to establish an effective and nationwide philanthropic culture among Malaysian citizen, especially Muslim, so that those who are in need will get their support, relieve and hope in facing the challenges of life. The philanthropic culture is expected to improve the quality of life of individuals and can also handle collective financial burdens of individuals and nations. The emphasis of Islam on philanthropic practices can be seen by the existence of zakat, alms and waqf.

\section{Background of the Study}

Philanthropic practices among Muslims can be the basis to fulfil human needs, reducing misery as well as resolving problems that can hinder human development in various aspects (Hasan et.al, 2013). Awareness of philanthropic practices has not yet become a culture in society, especially from government and statutory bodies. A record shows that from a total of RM287,310,121 only $22 \%$ of government employees paying zakat through salary deductions (Selangor Zakat Management Report 2016). A highly educated people together with those who are well-informed in economics and banking are also found to be less cultured in philanthropic practices as it is found that there is no specific method of education about it at higher education institutions (Mohd Farid \& Mohd Atef 2016). In fact, since The Wakaf Knowledge scheme was introduced at Universiti Kebangsaan Malaysia in 1999 only a total of RM380,000 was successfully collected until 2015 (Samsu et al., 2016).

In addition, despite the household income in Malaysia rising up to RM4585.00 and almost all households in Malaysia are reported to have more than one breadwinner, but the awareness of charity remains low. It is verified where $20 \%$ of the B40s still rely on BR1M contributions, working children's assistance and public donations (Basic Data of Malaysia 2017). The high debt problem amongst domestic households today is a critical issue for a harmonic community towards stable life. This is shown by the Central Bank of Malaysia Annual Report in 2016, where the household's debt to Gross Domestic Product (GDP) rate is $\mathbf{8 8 . 3}$ per cent. This data has recorded Malaysia as the country with the highest household debt in Asia (Bank Negara Report, 2017). The irregular income constraints and the pressures of world's modernization become a factor of today's society spending more than its ability. Additionally, unlimited requirements as well as unwise financial management open space for households to be indebted.

Therefore, there is a crucial need to develop philanthropic models to foster a voluntary contributing culture while reducing the burden of household debt in Malaysia (Nor Asmat Ismail, 2017). Even though Malaysia is one of the countries with the strongest economic growth (CIA World Fact Book 2017), oppositely philanthropy practices are not in line with it (Audrey Chia 2015). In comparison, Indonesia, which has a total of 134 billion of the 40,000 richest people, is ranked as 10th 
as a county that practice philanthropy compared to Malaysia which ranks 15th despite having almost three times the amount of wealth of 420 billion from 60 thousand people the richest in Malaysia. It is even more surprisingly that Myanmar is at the forefront of philanthropic cultures in the world (CAF World Giving Index, 2017).

Even the consistent and effective philanthropic practices are still inadequate to meet the needs of the community, especially the poor (Abdullah \& Ratnawati, 2013; Imran Hadi, 2011; Asmak, 2009). The lack of moral consciousness for a mutual help among each other is also a cause for this problem to remain continue (Anang Wahyu, 2017). In this case, conglomerates with high social and humanistic values have the potential to be the main contributor to philanthropic culture (Abdullah \& Ratnawati, 2013). Religious awareness also contributes (Abd. Halim et al., 2015; Amelia, 2008) especially in Malaysia and Indonesia (Audrey Chia, 2015; Janice, 2015).

Accordingly, Abdurohman (2016) proposed a social strengthening model with the distribution of funds for poor people, orphans, educational facilities, worship and community activities. Mohd Farid \& Mohd Atef (2016) on the other hand proposed to create a learning course in the institutions that emphasized the philanthropic aspects. Based on the above issues it is necessary to establish guidelines or manuals of philanthropic practices at the national level. Even until now the JAWHAR and the State Islamic Religious Council still have no special manual for donations or charity. It is hoped that with this manual the mentality of the community can be transformed to cultivate philanthropy in everyday life efficiently.

\section{Literature Review}

Philanthropy is a tool of distribution of property that is practiced throughout the world. Some terms are used in the Qur'an which refers to philanthropic nature which are divided into two categories which are obligatory such as zakat and circumcision such as alms, wakaf, infaq, grants and gifts (Abdiansyah Shah, 2015; Muhammad Sa'i, 2014; Hasan, 2013). According to the Oxford Dictionary, 'philanthropy' or philanthropos' is a desire to encourage the welfare of others by donating sincerely. Philanthropy is also described as an agency's activity or organizational involvement to promote something through gift or reward (Merriam Webster, 2018). Philanthropy is also viewed as a medium of gift in terms of time as well as valuable personal assets such as money and personal property for public purposes and benefits (Salamon, Lester $M, 1992)$. This encourages the community to volunteer to improve the quality of life and apply good deeds such as love, help and sharing practices in the society (Rawi et al., 2015).

This is because philanthropy can contribute to the development of national infrastructure, educational institutions, families to empower the economy and at the same time improving the standard of living (Tamin, 2011). Islamic philanthropy instruments are aimed at bridging social distance and reducing the gap of income distribution differs in the society (Zakaria et al., 2013). Some factors encourage philanthropic culture to preserve human well-being. One of them is obedience to religious orders. Interreligious and social linkages in addressing issues of poverty and natural disasters are very relevant to be applied through this philanthropy concept (Tamim, 2011 \& Latief, 2013).

Although there is a difference of views on philanthropy it does not preclude the success of philanthropy (Ismail et al., 2013). In addition, the role of the government in the formulation of administrative and constitutional patterns in line with the pattern of community development has 
also been a contributing factor (Makhrus, 2014). Bekkers \& Wiepking (2011) in the study also mentions that there are some basic theories that influence philanthropic cultures such as awareness of a need in society, an urgent demand for channeling donations, benefits to be gained, the nature of self-generosity, the contributors' reputation, the psychologist's effects of the recipients and the contributor as well as self-satisfaction earned. Rawi et al. (2015) adding the sustainability of educational institutions also contributes to the emphasis of philanthropy culture among the community.

While the barrier factors for the development of philanthropy culture are due to the shortage of alms funds at the national level. The misunderstanding on the use of philanthropy and zakat, do worsens the situation (Abdullaah Jalil, 2008). The problem of fund-raising, the leakage of alms funds, fraud and scammers is also identified (The Money Management Manual of Khairat JAWHAR, 2014). To embrace philanthropy, Fatimah in the previous study suggested that the distribution of funds was extended to welfare homes such as orphanages and old-folks homes (www.ikim.gov.my).

Additionally, distribution to non-governmental organizations or social welfare organizations is undertaken to run house-to-house campaigns to increase household income. In that way, philanthropic contributions have also increased. The government needs to play a role in terms of encouragement and monitoring so that funds are collected to the target group. (Makhrus, 2014). Tax exemption initiatives can also be extended to various philanthropic areas (Abdul Ghafar et al, 2013). An effective fundraising strategy by creating a win-win relationships between industries and corporate companies needs to be built (Sumrahadi \& Suryandari, 2013).

However, based on previous studies, there are also issues arising in relation to current philanthropic practices. Among them, local communities are not actively engaged in this activity. Low awareness of society, do contributes to the lack of community concerns to do charity. This was contributed by demographic factors, Muslim populations, household income as well as fund management methods. (Abdul Halim Sunny, 2007). There are other immoral issues such as fraudulent fund raising that allow these scams a chance to take advantage of the generosity of the Malaysian society (Official Statement of the State Council of Parliament, 2012).

Based on the findings in the Manual of Property Management published by JAWHAR, there has not been a comprehensive Manual of National Philanthropy to be used by all (www.jawhar.gov.my). Hence this study is very important in order to foster a culture of donation as well as to create a justice distribution within the society.

\section{Findings}

The implications of philanthropic cultural among the societies suggest a model of national philanthropic cultures. It aims to restructure the empowerment of philanthropic culture within the community in the country. The application method of philanthropic cultures is divided into target groups that are seen as capable in contributing philanthropy culture and increasing the amount of philanthropy funds.

This model is produced through research on philanthropy in Malaysia as well as ASEAN countries such as Singapore, Indonesia and Brunei. The empowerments of philanthropy culture in the regional countries become a construction measurement of a national philanthropic culture model. 
INTERNATIONAL JOURNAL OF ACADEMIC RESEARCH IN BUSINESS AND SOCIAL SCIENCES Vol. 8, No. 11, Nov, 2018, E-ISSN: 2222-6990 (C) 2018 HRMARS

This philanthropic culture model is expected to be a major reference for those involved in promoting, administering and managing philanthropy-related funds as this model has not been published by any related party. The philanthropic cultures model is as shown in Figure 1.0 below:

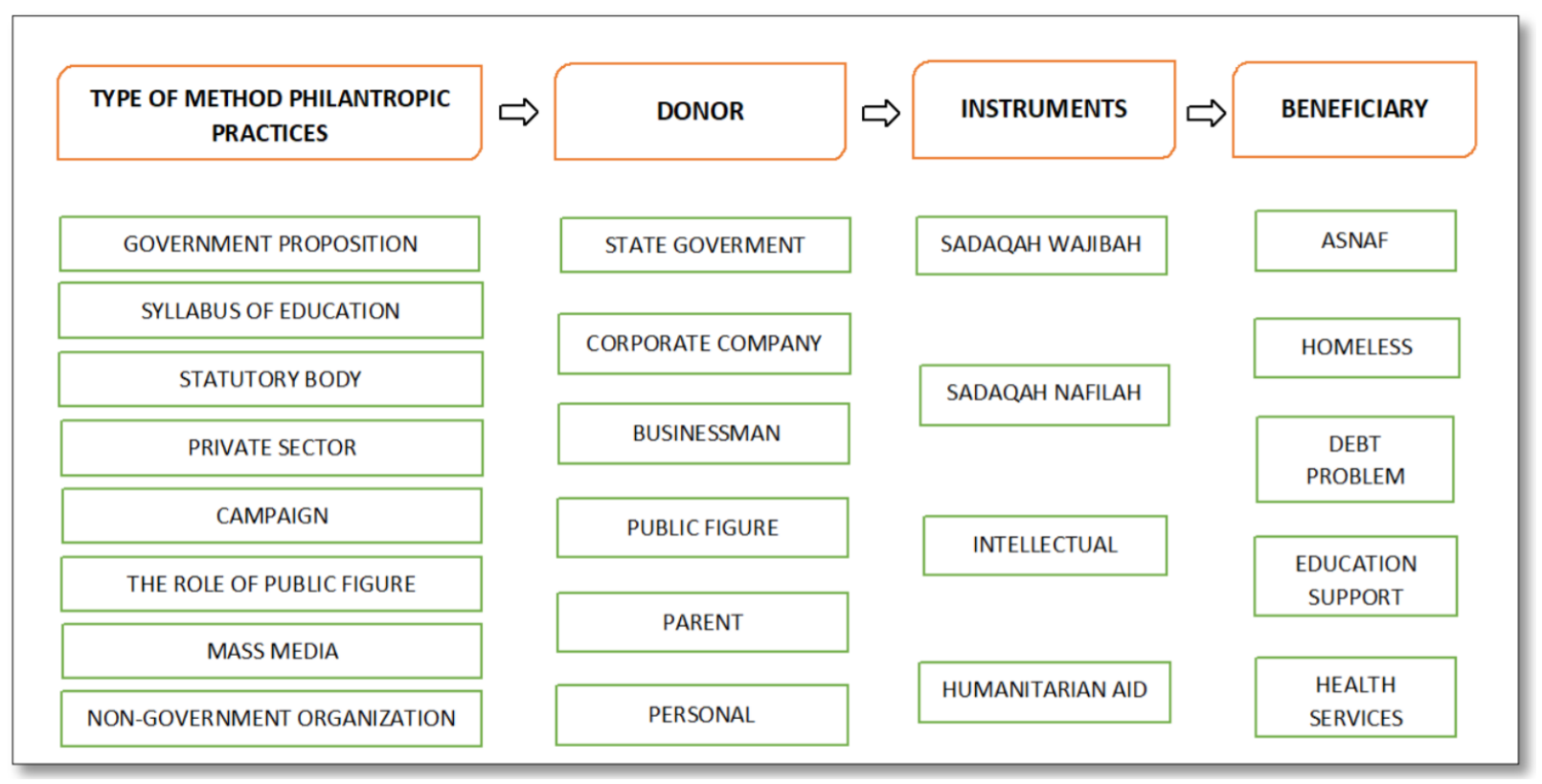

Figure 1.0; The National Model Of Philanthropic Practices

Based on the figure above, the application of philanthropic culture involves the role of various parties. The main focus on the need for understanding and togetherness for all levels of society are (i) explosive stimulus for philanthropy, (ii) philanthropy fund raising, (iii) philanthropic fund management and (iv) philanthropic fund allocation.

First of all, the government can apply this philanthropic culture by announcing the benefits of philanthropy and providing tax exemption incentives to donors, whether to civil servants or the corporate sector. At school as well as educational institutions, the value of giving and cultivating this philanthropy can be applied through the learning syllabus. Teaching and learning based on practical activities such as community service as well as a joint venture program with NGO's can inculcate philanthropic values in the students themselves. Through those experiential learning or active learning activities the value of philanthropy can be instilled since the school years. The implementation of this philanthropic culture does prevent an attitude of waiting for help from the authorities. Conversely, create a proactive standpoint in doing an effort as well as fostering care and concerns in every individual.

Subsequently, statutory bodies can also take on the role by assisting the government to carry out a campaign in order for this philanthropic value to be cultivated. Programs which approach underprivileged communities can be done through unions or clubs under their respective organizations. It goes the same with the private sector who succeed in corporate wakaf. 
A public figure who always becomes a center of attention can be ambassadors to promote philanthropy to the crowds. This group has their own strength where followers or fans have a tendency to follow anything that they do or say. Non-governmental organizations on the other hand can play a role by conveying knowledge on the importance of philanthropy to the public as well as become a medium that connect the contributors to those in need.

With this philanthropic culture, all parties such as state governments, corporate companies, entrepreneurs, public figure, parents and individuals can engage and benefit from the advantages of charity and donation. An understanding that needs to be fostered is contribution that will be given is not necessarily in the form of material. On the other hand, such contributions can be energy, ideas, knowledge, expertise and skills to solve problems that arise among society.

Therefore, the needy and less fortunate groups such as the asnaf, homeless, debt stricken individuals and the students who seek knowledge can be helped effectively. In addition, with this philanthropic culture, those who need help in education and medical treatment have benefited accordingly. Thus, all members in society can enjoy a quality and prosperous life

\section{Conclusion}

In conclusion, this philanthropic culture is very important to emphasize and highlight among Malaysians in assisting the development and progress of Malaysia to be more rapid and accomplishing. In addition, these philanthropic cultures can indirectly help lighten various problems such as debt, poverty among low-income people and improve the quality of life.

The potential of philanthropy in Islam can be increase by manipulate or commercialized the philanthropy property and bring back the advantages to the philanthropy funds. However, attention should be given to aspects financial reports to ensure that all transactions done adhere to the best governance and avoidance there may be deviations and wastes philanthropy funds. (Asharaf \& Abdullaah Jalil 2014). It is hoped that this model can be a reference and guide to all parties in practicing philanthropy directly or indirectly to ensure the well-being of life.

\section{Acknowledgement}

Universiti Teknologi Mara Cawangan Johor, Kampus Pasir Gudang; Academy Of Contemporary Islamic Studies (ACIS)

\section{Corresponding Author}

Mohd Farhan Ahmad, Lecturer of Universiti Teknologi Mara Cawangan Johor Kampus Pasir Gudang; farshah04@gmail.com, Jalan Purnama, Bandar Seri Alam, 81750 Masai, Johor, Malaysia 
INTERNATIONAL JOURNAL OF ACADEMIC RESEARCH IN BUSINESS AND SOCIAL SCIENCES

Vol. 8, No. 11, Nov, 2018, E-ISSN: 2222-6990 (C) 2018 HRMARS

\section{References}

Jalil, A. \& Muda, M. (2008). Pengurusan Dana Sedekah Secara Sistematik: Analisa Peranan Institusi Kerajaan Dan Swasta. JAWHAR, 1-14.

Kasdi, A. (2016). Filantropi Islam Untuk Pemberdayaan Ekonomi Umat (Model Pemberdayaan ZISWAF di BMT Se-Kabupaten Demak). Iqtishadia 9(2), 227-245

Alam, N. (2010). Islamic venture philanthropy: A tool for sustainable community development. Available at http://dx.doi.org/10.2139/ssrn.1565859.

Alterman, J. B., Hunter, S., \& Phillips, A. L. (2016). The Idea and Practice of Smart Cities in India. Arlington, Va: International Business Initiatives.

Fauzia, A. (2013). Faith and the State: A History of Islamic Philanthropy in Indonesia. The University Of Melbourne.

Wahyu, A. (2017). Filantropi Islam Sebagai Stabilitas Kehidupan. Jurnal Studi Agama Islam, 10(1), 111-134.

Ramli, A. M. \& Jalil, A. (2014). Model Perbankan Wakaf Korporat: Analisis Wakaf Selangor Muamalat. Jurnal Pengurusan, 42, $159-167$

Rahman, A. A. (2009). Peranan Wakaf Dalam Pembangunan Ekonomi Umat Islam Dan Aplikasinya Di Malaysia. Jurnal Syariah, 17(1), 113-152

Chia, A. (2015). Potential And Prospects For Philanthropy In Implementing Post-2015 Development Goals. Manila: Asian Development Bank.

Bekkers, R., \& Wiepking, P. (2011). A Literature Review of Empirical Studies of Philanthropy: Eight Mechanisms That Drive Charitable Giving. Nonprofit and Voluntary Sector Quarterly.

Charles, M. V. (2006). Industry, Philanthropy, and Universities: The Roles and Influences of the Private Sector in Higher Education. In Research \& Occasional Paper Series. Berkeley: University Of California.

Hashim, M. F. A. M., \& Yusof, M. 'Atef M. (2016). Corporate Philanthropy Disclosure : Does Board's Education Matters ? Journal for Studies in Management and Planning, 2(2), 325.

Latief, H. (2013). Agama Dan Pelayanan Sosial: Interpretasi Dan Aksi Filantropi Dalam Tradisi Muslim Dan Kristen Di Indonesia. Religi, 9(2), 174-189.

Tamin, I. H. (2011). Peran Filantropi Dalam Pengentasan Kemiskinan Di Dalam Komunitas Lokal. Jurnal Sosiologi Islam, 1(1), 35-58.

Ismail, A. G., Zaenal, M. H., \& Shafiai, H. (2013). Philanthrophy in Islam : A Promise to Welfare Economics System. Proceedings of World Universities' Islamic Philanthropic 2013, 1-23.

Jandhyala, B. G. T. (2006). Private Higher Education: Philanthropy to Profits. In Higher Education In The World 2006. 113-121.

Janice, L. H. N. (2015). Global Financial Crisis and Philanthropy : Malaysian Case. Cosmopolitan Civil Societies Journal, 7(2), 19-32.

Olberding, J.C. (2011). Does Student Philanthropy Work? A Study Of Long-Term Effects Of The ,Learning By Giving Approach. Innovative Higher Education, 37(2), 71-87

Jusuf, C. (2007). Filantropi Modern Untuk Pembangunan Sosial. Jurnal Penelitian Dan Pengembangan Kesejahteraan Sosial, 12(1), 74-84. 
Keidan, C., Pharoah, C., \& Mckenzie, T. (2014). Philanthropy Education in the UK and Continental Europe: Current Provision, Perceptions and Opportunities. In CGAP Occasional Paper Philanthropy Education in the UK and Continental Europe, London. 1-54.

Lembaga Penduduk Dan Pembangunan Keluarga Negara. (2016). Laporan Index Kesejahteraan Keluarga Malaysia 2016. Kuala Lumpur: Perpustakaan Negara Malaysia.

Makhrus. (2014). Aktivisme Pemberdayaan Masyarakat Dan Institusionalisasi Filantropi Islam Di Indonesia. Islamadina, 13(2), 26-44.

Mangaleswaran, R., Vekataraman, R. (2013). Designing Philanthropy for Impact Giving To the Biggest Gaps in India. Mckinsey \& Company, Inc. 1-40

Mokhzani, C. W. Bin. (2016). Kemiskinan Dan Pendapatan Isi Rumah. Khazanah Research Institute. Sumrahadi, A., \& Suryandari, R. Y. (2013). Praktik Filantropi Sosial Bagi Pembangunan Aktiviti Seni Dan Budaya: Suatu Wacana. Geografia: Malaysian Journal of Society and Space, 9(3), 95106.

Unit Perancang Ekonomi. (2012). Kualiti Hidup Malaysia 2011. Putrajaya: Pencetakan Nasional Malaysia Berhad.

World Health Organization. (2011). World Report On Disability. American Journal of Physical Medicine Rehabilitation Association of Academic Physiatrists (Vol. 91). Malta: World Health Organization.

Zachau, U., Hadad-Zervos, F. H., \& Shetty, S. (2017). Malaysia Economic Monitor: Data for Development. Kuala Lumpur: Global Knowledge \& Research Hub.

Zaenal, M. H., \& Ismail, A. G. (2014). Islamic Philanthropy : Rationality for a New Economics Welfare System. 155-181.

Zaenurrosyid, A. (2016). Filantropi Islam Berbasis Harta Wakaf Masjid (Studi Atas Model Pengelolaan Wakaf Masjid Agung Bersejarah Di Jawa. Jurnal Bimas Islam, 9(3), 521-556.

Zakaria, A. A. M., Samad, R. R. A., \& Shafii, Z. (2013). Venture Philanthropy Waqf Model: A Conceptual Study. Jurnal Pengurusan, 38, 119-125. 